ㅇ. Length 82 millim., width 8 .

o. Length 85 millim., width $6 \cdot 3$.

Loc. Chusan Island (J. J. Walker, 2 ơ, 2 \&); Da-laenSaen, 30 miles S.W. of Ningpo, 500-2500 feet alt. (J. J. Walker, 1 o ).

The example from the latter locality has fifty-six pairs of legs, but otherwise does not appear to differ from those that were taken at Chusan Island.

This species is evidently nearly allied to $S$. exquisitus of Karsch (Zeitschr. Naturwissen. (3) vi. p. 57) from Pekin ; but Karsch says of the latter: "annulis profunde segmentatis," and asserts that the pores are situated "ante sulcum sat profundum longitudinalem partis posticee."

In $S$. Walkeri, however, there is only sometimes a trace of this latter sulcus, and the transverse sulcus, which Karsch describes as profound, is entirely obsolete dorsally and very weak at the sides.

Spirobolus Bungii of Brandt, also from Pekin, may be identical either with exquisitus or Walkeri. In fact, were it not for the difference of locality, I should scarcely have felt justified in describing Walkeri as distinct from Bungii.

\title{
Supplementary Note upon Herr Verhoeff's Subdivisions of the so-called Genus Iulus.
}

I feel that I cannot altogether pass over the genus Iulus without commenting upon a revision of the group that Herr Verhoeff has recently proposed (Zool. Anz. xvi.p.479 \&c., 1893; and Verh. z.-b. Ges. Wien, 1894, pt. ii. p. 137, \&c., 1894). The anatomical part of this work is, it seems to me, worthy of all praise; and I cannot but congratulate the author upon the industry and perseverance he has shown in elucidating many points of morphological importance. But his supreme disregard for, or entire ignorance of, the fundamental principles of zoological nomenclature is certainly astonishing. It has resulted, moreover, in the creation of an immense amount of wholly unnecessary confusion, the unravelling of which will prove to be a task of no small difficulty. I have here taken upon myself to attempt to correct some of the more glaring errors, in order that they may penetrate no further into literature. Firstly, however, to avoid ambiguity, I venture to lay down the following propositions, which, I take it, will be generally admitted by most thoughtful systematic workers :-

A genus must contain one of the species originally referred 
to it by its founder. For purposes of nomenclature generic and subgeneric terms are equivalent. If a genus be split into two or more subgenera, the subgenus which contains the type species of the genus must receive the generic name. A generic or subgeneric name must not be consigned to oblivion on the grounds that the species referred to it prove to be capable of finer division; nor yet upon the grounds that the character upon which it was based proves in itself to be not of generic, or subgeneric, or even specific value. It can only be finally sunk as a synonym when it has been shown that its type species possesses no other character of generic or subgeneric importance. And, lastly, when a generic name has once been published by an author, neither he nor anyone else has the power to replace it by another, unless preoccupied, nor yet to transfer it from one set of species to another.

Herr Verhoeff seems to me to have disregarded all these rules; nor has he been careful to avoid the use of names already in vogue. An instance or two will illustrate my meaning :-The type of Iulus, Linn., must be either sabulosus or terrestris; but neither of these species is referred to Iulus by Verhoeff. The species named Iulus foetidus by Koch received the subgeneric name Unciger from Brandt; but, for no valid reasons, Verhoeff proposes Oncoiulus for the same species. The genus Pachyiulus of Berlese is adopted, but it is divided into two subgenera-Megaiulus and Acanthoiulus; but Megaiulus is equivalent to Pachyiulus, and Acanthoiulus was used over fifty years ago for perhaps the best-marked genus in this same group of Diplopoda. Leptoiulus includes fallax of Meinert, which is the type of Ophiulus of Berlese; and since it appears to be admitted that trilineatus, Koch, the type of Leptoiulus, is congeneric with fallax, it is clear that Leptoiulus is a synonym of Ophiulus. Brachyiulus of Berlese and Anoploiulus, Verhoeff, are synonyms, because they have the same type species, pusillus, Leach; and Leucoiulus is similarly synonymous with Allaiulus, \&c., \&c. To pursue further the inquiry as to the stability of the other genera and subgenera proposed would be beyond my present purpose; but the following table will, I think, show, at all events approximately, the genera and subgenera of European Iulidæ.

I may add that, since Herr Verhoeff has not seen the necessity to state which species out of a number is the type of a genus or subgenus, I have here ventured to save him this trouble by selecting the first.

1. Iulus, Linn. (=Ommatoiulus, Latz.; Archiulus, Berl.; Mesoiulus, Verh. 1893, not 1894; Bothroiulus, Verh. 1894).

Type sabulosus, L. 
2. Unciger, Brandt, 1841 (= Oncoiulus, Verh.).

Type fotidus, Koch.

3. Allaiulus, Koch, 1847 (=Leucoiulus, Verh.).

Type molybdinus, Koch.

4. Pachyiulus, Berl. (=Megaiulus, Verh.).

Type varius (Fabr.).

5. (New name wanted) (=Acanthoiulus, Verh., preoccupied).

Type fuscipes, Koch.

6. Ophiulus, Berl. (=Leptoiulus, Verh.).

Type fallax, Mein.

7. Brachyiulus, Berl. (=Anoploiulus, Verh.).

Type pusillus, Leach.

8. Diploiulus, Berl.

Type rufifrons, Koch.

9. Mesoiulus, Berl. (not Mesoiulus, Verh.).

Type paradoxus, Berl.

10. Typhloiulus, Latz.

Type psilonotus, Latz.

11. Micropodiulus, Verh. (=Ophiulus, Berl., in part).

Type ligulifer, Latz.

12. Xestoiulus, Verh.

Type blaniuloides, Verh.

13. Cryptoiulus, Verh.

Type italicus, Latz.

14. Cylindroiulus, Verh. (= Diploiulus, Berl., in part).

Type silvarum, Mein. (=punctatus, Leach).

15. Chromatorulus, Verh.

Type podabrus, Latz.

16. Palaoiulus, Verh. (=Eleutheroiulus, Verh.).

Type Oliveira, Verh.

17. Hemipodiulus, Verh. (=Mesoiulus, Verh. 1894, not 1893 ; not Mesoiulus, Berl. 1885).

Type Karschi, Verh.

18. Tachypodoiulus, Verh.

Type albipes, Koch.

\section{EXPLANATION OF PLATE XI.}

Fig. 1. Geophilus (?) Holstii. Head and maxillipedes from above.

Fig. 1 a. Ditto. Anal somite from below.

Fig. 2. Orthomorpha roseipes. External aspect of copulatory foot.

Fig. $2 a$. Ditto. Apex of the same.

Fig. 2 b. Ditto. Caudal process (tubercles exaggerated).

Fig. $2 c$. Ditto. Anal sternite.

Fig. 3. Strongylosoma Holstii. Left copulatory foot from below.

Fig. 4. Polydesmus Moorei. Keel of twelfth segment.

Fig. 5. Polydesmus paludicola. Keel of twelfth segment.

Fig. 6. Polydesmus compactus. Keel of tenth segment.

Fig. 7. Polydesmus dentiger. Keel of eleventh segment.

Fig. 7 a. Ditto. Antenna.

Fig. 7 b. Ditto. Anal sternite. 
Fig. 8. Fontaria lacustris. Left copulatory foot from below.

Fig. $8 a$. Ditto. Keel of thirteenth segment.

Fig. $8 b$. Ditto. Anal sternite.

Fig. 9. Fontaria Holstii. Left copulatory foot from below.

Fig. 9 a. Ditto. Ditto, external view.

Fig. 10. Fontaria neptunus. Left copulatory foot from below.

Fig. 11. Fontaria coarctata. External aspect of copulatory foot.

Fig. 12. Paraiulus coreanus. Lateral view of head and first segment.

Fig. 12 a. Ditto. Protruded portion of copulatory apparatus.

Fig. 13. Iulus vallicola. Lateral view of tergites 1 and 2.

Fig. 14. Spirobolus Walkeri. Anterior view of half the copulatory apparatus.

Fig. 14 a. Ditto. Inner protrusible portion of copulatory apparatus.

Fig. 15. Fontaria variata. Left copulatory foot from below.

Fig. 15 a. Ditto. Ditto, outer view.

\section{XLIV.-On a new Species of Hesperiidæ of the Genus Amenis,} Watson. By F. D. Godman and O. Salvin.

Mr. O. T. Baron, who is now travelling in Northern Peru, recently sent us a series of a remarkable species of Hesperiidæ which he captured near Cajamarca at an altitude of 10,000 feet above the sea. The species belongs to Mr. Watson's genus Amenis (P. Z. S. 1893, p. 12), the wing-structure being very similar to that of $A$. pionia, the type of the genus. The cell of the primaries is long and narrow, and the discocellulars very oblique, as in that species; the third median segment is relatively still shorter than in $A$. pionia. The wings are shorter, the secondaries not so produced at the anal angle, the outer margin being rounded; the radial of the secondaries is obsolete; and the hind tibiæ, being thickly scaled, do not clearly show the proximal pair of spurs.

\section{Amenis Baroni, sp. n.}

Costa of primaries slightly curved, outer margin convex; anal angle of secondaries very slightly produced. Primaries golden olive, the outer and inner margins broadly black; veins black; a transverse series of three black-bordered red spots, the largest in the cell, the others below in the direction of the inner margin; a cluster of four orange-red spots beyond the ceil in a black border, another of two spots in the disk : secondaries black, with two irregular bands of golden olive, one submarginal, the other through the cell, the two meeting near the anal angle; fringes of both wings buff. Underside: primaries as above, the lowest spot of the transverse band orange-buff; a large patch of black on the inside of this band: secondaries greenish buff, the outer and inner margins, two narrow irregular lines across the disk, a single 

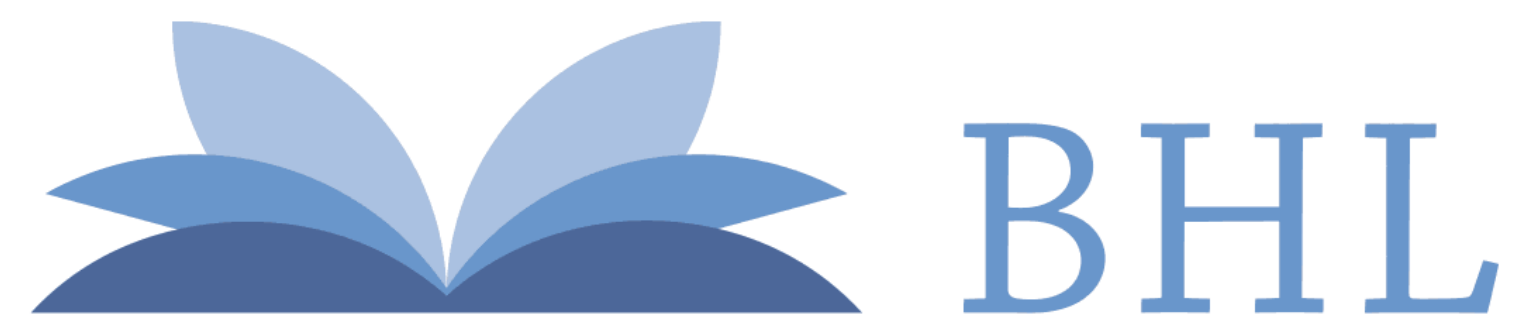

\section{Biodiversity Heritage Library}

1895. "Supplementary note upon Herr Verhoeff's subdivisions of the so-called genus Iulus." The Annals and magazine of natural history; zoology, botany, and geology 15, 369-372. https://doi.org/10.1080/00222939508677896.

View This Item Online: https://www.biodiversitylibrary.org/item/54281

DOI: https://doi.org/10.1080/00222939508677896

Permalink: https://www.biodiversitylibrary.org/partpdf/53502

\section{Holding Institution}

Smithsonian Libraries

\section{Sponsored by}

Smithsonian

\section{Copyright \& Reuse}

Copyright Status: Public domain. The BHL considers that this work is no longer under copyright protection.

This document was created from content at the Biodiversity Heritage Library, the world's largest open access digital library for biodiversity literature and archives. Visit BHL at https://www.biodiversitylibrary.org. 